\title{
TOXICOLOGICAL AND BIOCHEMICAL EFFECTS OF PRECOCENE II AGAINST COTTON LEAFWORM, SPODOPTERA LITTORALIS (BOISD.)
}

\author{
FAHMI, A. A. ${ }^{1}$; M. I. NASSAR ${ }^{2}$; E. S. MANSOUR ${ }^{3}$; \\ A.M. ABAZA ${ }^{3}$; RANIA A. SALAMA. ${ }^{3}$ \\ 1- Chemistry Department, Faculty of Science Cairo University. \\ 2- Entomology Department, Faculty of Science Cairo University. \\ 3- Plant Protection Research Institute, ARC., Dokki, Giza, Egypt.
}

(Manuscript received 31 March 2019)

\begin{abstract}
$\mathrm{T}$ he cotton leafworm, Spodoptera littoralis (Boisd.) is very polyphagous insect against the most economic plants all over the world. The traditional synthetic chemical insecticides had dramatic effect on the living organisms including man. Anti-juvenile hormones; precocene II effect on the cotton leafworm, Spodoptera littoralis were assayed under laboratory conditions. (PrecoceneII (6,7-dimethoxy-2,2dimethylchromene) was the main constituent isolated from Ageratum houstonianum plant. The compound caused toxicity against the larvae with $\left(L_{10}\right.$ was $\left.5.59 \mathrm{mg} / \mathrm{l}\right)$, ( $\left(C_{25}\right.$ was $\left.24.69 \mathrm{mg} / \mathrm{l}\right)$ and $\left(L C_{50}\right.$ was 128.53 $\mathrm{mg} / \mathrm{l})$. There was some morphogenic effect obtained due to effect of precoceneII on larvae, pupae and adult stages. On the other hands the biochemical analysis of the cotton leafworm revealed that precocene II caused significant increase in chitinase, protease and total carbohydrates with $(17.32,50.17$ and $36.85 \%$ ), respectively comparison to control.

Keywords: Biochemical analysis, toxicology, Precocene II, IGRs, Antijuvenile hormone, Spodoptera littoralis
\end{abstract}

\section{INTRODUCTION}

The cotton leafworm, Spodoptera littoralis (Boisd.) is a most important polyphagous pest, while it is widely distributed all over the world. Larvae of this pest can feed on many of the economically important plant species belonging to 40 families and the rate of development has a strong nutritional component (Brown and Dewhurst, 1975).

Commonly, the control of this pest has largely been depending on the synthetic insecticides; chlorinated hydrocarbons, organophosphates, carbamates and pyrethroids (Baldwin and Graves, 1991). Among the problems associated mainly with the excessive application of synthetic insecticides is rising the resistant populations of pathogens and pests and environmental hazards.

For the production of foodstuffs of such quality to be possible, it is necessary among other things, to reduce the risks associated with excessive application of synthetic insecticides.

The corpora allata is endocrine gland of insect which secrete juvenile hormones that affect the regulation of metamorphosis and the development of gonads. Juvenile 
hormone $(\mathrm{JH})$ is necessary for insect development throughout the immature stages (Staal, 1986). It works alone or in combination with ecdysone and its metabolite 20E (20-hydroxyecdysone) in regulating various functions (Nijhout, 1994). JHs play important roles in several physiological processes, such as reproduction, diapause, behavior, polymorphism, migration, metabolism and innate immunity (Truman and Riddiford, 2007; Flatt et al., 2008).

Most compounds that belong to the IGR class are not stomach or neurotoxic poisons, but have a unique mode of action that disrupts the molting process or cuticle formation in insects (Smagghe and Degheele, 1994) or interferes with the hormonal balance of insects (Dhadialla et al., 1998), they are characteristically slow acting against a narrow range of sensitive stages of the insects' life cycle with harmful effect against target pest.

Anti-juvenile hormone compounds (Precocene) are effective insect growth regulators of some insect species (Bede et al., 2001), where inhibiting the biosynthesis of juvenile hormones of the corpora allata and the insufficiency of these substances exert some abnormalities in certain biological phenomena, which are controlled by the juvenile hormones (Bowers, 1985).

Plants defend themselves by producing natural products that are effective against herbivores. Precocene II is a chromene derivative from 2,2Dimethylchromenes which are characteristic natural products found in many species of the Asteraceae (Proksch and Rodriguez, 1983). Bowers et al., (1976) showed that the Precocene II (6,7-dimethoxy-2,2-dimethylchromene) is a compound isolated from Ageratum houstonianum plant which reveal the growth-disrupting properties of certain species of insects by causing a deficiency of juvenile hormone in insects.

Precocene II is known as an active anti-juvenile hormone in susceptible insect species because of its lethal action in a broader range of insects

(Randriaminahy, 1992).

Thus, the aim of the current study was to investigate the influence of precocene II on the toxicological and biochemical parameters on the $4^{\text {th }}$ instar larvae of $S$. littoralis.

\section{MATERIALS AND METHODES}

\section{Insect rearing:}

The susceptible strain of the cotton leafworm, Spodoptera littoralis (Boisd.) was obtained from the Cotton Pesticides Evaluation Research Department in plant protection Research institute, Dokki, Giza, Egypt, and was maintained in climatic chamber under optimum conditions of $25^{\circ} \mathrm{C} \pm 2$ and $65 \pm 5 \% \mathrm{RH}$ and (16L:8D) light: dark photoperiod. The culture was kept and reared on castor bean leaves as described by El-Defrawi et al., (1964). 


\section{Precocene II:}

Precocene II was obtained from Sigma-Aldrich Chemical Company. It was dissolved in acetone solvent, $1 \mathrm{gm}: 1 \mathrm{ml}$, and serial concentrations was prepared.

\section{Toxicological test:}

By using leaf dipping technique, Castor bean leaves were dipped for 30 seconds in each concentration $(50,100,200,400$ and $800 \mathrm{mg} / \mathrm{l})$ then left to dry. The treated leaves were offered to newly molted $4^{\text {th }}$ instar larvae of $S$. littoralis for $48 \mathrm{hrs}$. Parallel with control larvae without any treatment. Mortality percentages were recorded after 24 hrs., then corrected according Abbott's formula (1925). From the corrected mortality percentages the corresponding toxicity lines (LC-P lines) were estimated in addition to determine $\mathrm{LC}_{10}, \mathrm{LC}_{25}$ and $\mathrm{LC}_{50}$ values and their confidence limits, slope values of tested extract were also estimated.

\section{Biochemical assay:}

The survived larvae after feeding on the leaves treated with the different concentrations of precocene II were taken to determine the biochemical activity of total carbohydrate, chitinase and protease enzymes.

\section{Preparation of homogenate samples for biochemical analysis:}

By using a Teflon homogenizer (Mechianika Precyzyjna Warszawa type MPN-309Poland) at $500 \mathrm{rpm}$, the collected larvae were homogenized in distilled water for 3 minutes. Homogenates were collected in cold tubes (on ice) previously coated with crystals of phenylthiourea to prevent melanization. by using (BECKMAN GS-6R Centrifuge), the cold tubes were Centrifuged for $10 \mathrm{~min}$. at $6000 \mathrm{rpm}$ at $5^{\circ} \mathrm{C}$, the formed supernatant fluid during the centrifugation was divided to aliquots each of $(0.5$ $\mathrm{ml}$ ) and it was kept at $-20^{\circ} \mathrm{C}$ until analysis.

\section{Biochemical impacts:}

\section{1- Chitinase enzyme activity}

According to Ishaaya \& Casida (1974) method, the free aldehydic groups of hexoaminase liberated on chitin digestion is determining using 3.5-dinitrosalicylic acid as a reagent to assay chitinase.

\section{2- Protease enzyme activity:}

Protease was assayed by using Tachell et al., (1972) method which evaluate the increase of the free-amino acids that are separated from albumin in the period of incubation at $30^{\circ} \mathrm{C}$ for an hour.

\section{3- Total carbohydrate assay:}

Total carbohydrates were estimated in acid of sample by the phenol-sulphuric acid reaction of Dubois et al., (1956). Total carbohydrates were extracted and prepared according to Crompton and Birt (1967). 


\section{Morphogenic effect:}

The treated $4^{\text {th }}$ instar larvae of $S$. littoralis with precocene II produced many abnormalities for the different developmental stages. This was including abnormal larvae, pupal-larval intermediate and abnormal adults.

\section{RESULTS AND DISCUSSIONS}

\section{Toxicological impacts:}

The experiments were carried out to evaluate the toxicological activity of Precocene II against the $4^{\text {th }}$ instar larvae of $S$. littoralis under laboratory conditions.

From data in Table (1) Precocene II concentrations caused lethality and morphogenic effects against the $4^{\text {th }}$ instar of $S$. littoralis.

Table 1. Accumulative mortality percentages of $S$. littoralis larvae after treatment with precocene II under laboratory conditions

\begin{tabular}{|c|c|c|c|}
\hline \multirow{2}{*}{$\begin{array}{c}\text { Concentrations } \\
(\mathrm{mg} / \mathrm{l})\end{array}$} & \multicolumn{3}{|c|}{ Accumulative mortality percentages \% } \\
\cline { 2 - 4 } & 3 days post treatment & 7 days post treatment & $\begin{array}{c}\text { 14 days post } \\
\text { treatment }\end{array}$ \\
\hline 50 & 3.33 & 16.67 & 33.33 \\
\hline 100 & 5 & 20 & 46.67 \\
\hline 200 & 8.33 & 33.33 & 60 \\
\hline 400 & 15 & 45 & 66.67 \\
\hline 800 & 16.67 & 53.33 & 76.67 \\
\hline
\end{tabular}

Table 2. Toxicity data of Precocene II against the $4^{\text {th }}$ instar larvae of $S$. littoralis under laboratory conditions.

\begin{tabular}{|c|c|c|c|c|}
\hline \multirow{4}{*}{$\begin{array}{c}\text { Toxicity } \\
\text { parameters }\end{array}$} & $\begin{array}{c}\mathrm{LC}_{10} \\
\text { (Confidence limits) } \\
\mathrm{mg} / \mathrm{l}\end{array}$ & $\begin{array}{c}\mathrm{LC}_{25} \\
\text { (Confidence limits) } \\
\mathrm{mg} / \mathrm{l}\end{array}$ & $\begin{array}{c}\mathrm{LC}_{50} \\
(\text { Confidence limits) } \\
\mathrm{mg} / \mathrm{l}\end{array}$ & Slope $\pm \mathrm{SE}$ \\
\cline { 2 - 5 } & $\begin{array}{c}5.59 \\
(1.27-12.82)\end{array}$ & $\begin{array}{c}24.69 \\
(10.07-41.57)\end{array}$ & $\begin{array}{c}128.53 \\
(90.39-170.07)\end{array}$ & $0.941 \pm 0.139$ \\
\hline
\end{tabular}

By using LC-P program; $\mathrm{LC}_{10}, \mathrm{LC}_{25}, \mathrm{LC}_{50}$ and slope values were used as parameters in evaluation the insecticidal activity of this compound. The $\mathrm{LC}_{10}, \mathrm{LC}_{25}$, $\mathrm{LC}_{50}$ values were recorded in Table (2), where they were; 5.59, 24.69 and 128.53 $\mathrm{mg} / \mathrm{l}$, respectively.The lower and upper confidence limits were ranged between 1.27$12.82,10.07-41.57$ and $90.39-170.07 \mathrm{mg} / \mathrm{l}$ for $\mathrm{LC}_{10}, \mathrm{LC}_{25}, \mathrm{LC} \mathrm{C}_{50}$ respectively, as shown in Table (2).

As mentioned before according to Bowers et al., (1976) noted that precocene II induces premature metamorphosis and/or cessation of other juvenile hormonemediated functions.

The Chemicals of Plants produce a resistance against herbivorous insects under natural conditions. Due to the antihormonal activity of precocene II, a metabolic fate in the insect's diet has received considerable attention (Bergot et al., 1980; Ohta et al., 1977; Soderlund et al., 1980). 
The obtained results are compatible with Srivastava and Proksch (1991); which found that precocene II has shown an exhibit venomousness and feeding deterrence to the Noctuid species which are a type of herbivorous insects.

\section{Morphogenic abnormality:}

After treatment $4^{\text {th }}$ larval instars with precocene II produced morphogenic effect to larvae, pupae and adult stages of $S$. littoralis. These abnormalities appeared that larva was wrinkled with black colour and pupa was appeared as larval-pupal intermediate form, while adult was emerged without wing and shortened of wing or immobilized legs.

\section{Biochemical impacts:}

The biochemical parameters of the survived larvae of $S$. littoralis after treatment with the sub-lethal concentration were evaluated; the effect of precocene II on some enzyme activities related to metamorphosis; chitinase, protease and total carbohydrates.

Theses biochemical impacts were undertaken as an attempt to interpret the primary mechanism of action of this concentration.

Table 3. Biochemical parameters in haemolymph after treatment the $4^{\text {th }}$ instar larvae of $S$. littoralis with the LC ${ }_{50}$ of Precocene II.

\begin{tabular}{|c|c|c|c|}
\hline Parameters & Control & $\begin{array}{c}\text { Precocence } \\
\text { treatment }\end{array}$ & Change \% \\
\hline $\begin{array}{c}\text { Chitinase } \\
\boldsymbol{\mu g ~ N - a c e t y l ~ g l u c o s a m i n e ~} \\
\text { /min./g b. wt }\end{array}$ & $1472 \pm 54.79$ & $1727 \pm 48.22^{*}$ & 17.32 \\
\hline $\begin{array}{c}\text { Protease } \\
\boldsymbol{\mu g a l a n i n ~ / m i n . / g ~ b . ~ w t ~}\end{array}$ & $45.13 \pm 1.02$ & $67.77 \pm 1.45^{*}$ & 50.17 \\
\hline Total Carbohydrates & $6.16 \pm 0.01$ & $8.34 \pm 0.13^{*}$ & 36.85 \\
\hline
\end{tabular}

Results in Table (3) and Fig. (1) Showed that treatment of the $4^{\text {th }}$ instar larvae with the sub-lethal concentration of precocene II caused a significant at $\mathrm{P}<0.5$ increase in chitinase activity with $(17.32 \%)$ more than in control. While protease enzyme activity with $50.17 \%$ more than control, and total carbohydrates with 36.85 $\%$ more than control.

Insect juvenile hormones $(\mathrm{JH})$ might antagonize JH-action (Bowers, 1976). It was found that that activity of chromenes (precocene II) isolated from Ageratum houstonianum plant. In sensitive insects treated with these compounds (anti-JHs). JHdeprivation is signaled by precocious metamorphosis in immature stages and sterility in adult female's insects (Anthonsen \& Chantarasakul, 1970; Bowers et al., 1976; Pratt, 1983; and Staal, 1986). 


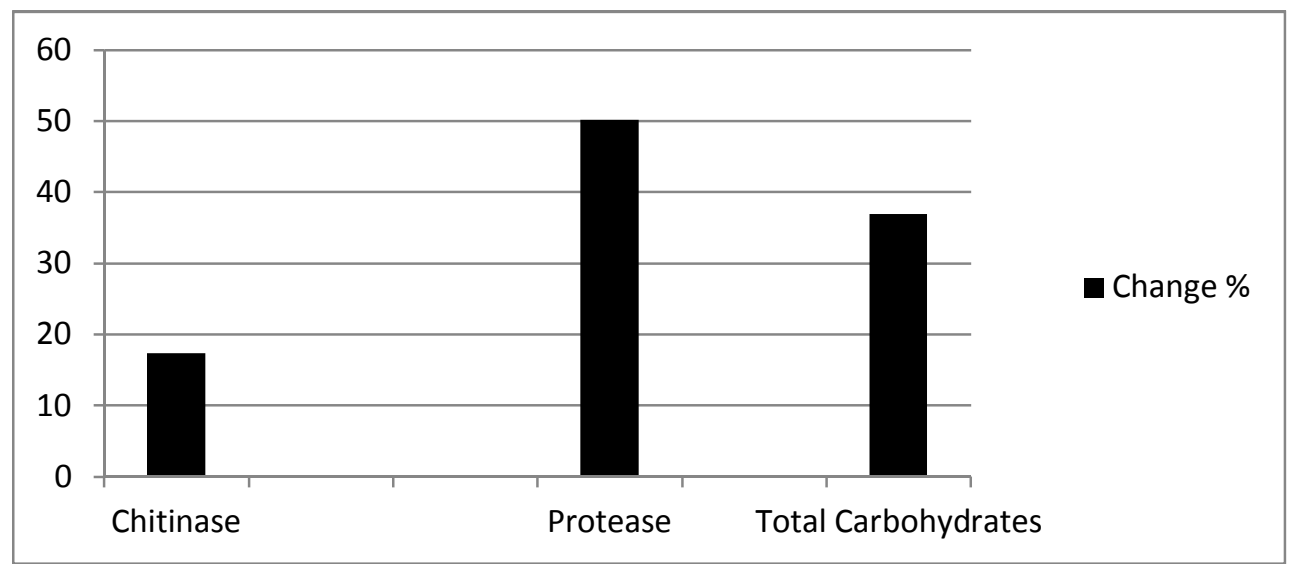

Fig. 1. Change percentage of biochemical parameters in haemolymph of the $4^{\text {th }}$ instar larvae of $S$. littoralis after treatment with $\mathrm{LC}_{50}$ of Precocence II.

\section{REFERENCES}

1. Abbott, W.S. 1925. A method ofcomputing the effectiveness of aninsecticide.J. Econ. Entomol., 18:265-267.

2. Anthonsen, T. and S. Chantarasakul 1970. Ageratone and dihydroageratone, new benzofuran derivatives from Ageratum houstonianum Mill. Acta Chem. Scand. 24: 721-722.

3. Baldwin, J.L. and J.B. Graves 1991. Cotton insect pest management. LA Coop. Ext. Serv. Bull.,1829.

4. Bede, J.C.; Teal, P.E.; Goodman, W.G. and Tobe, S.S. 2001. Biosynthetic pathway of insect juvenile hormone III in cell suspension cultures of the sedge Cyperusiria. Plant Physiol., 127(2): 584-593.

5. Bergot, B.J.; K.J. Judy; D.A. Schooley and L.W. Tsai 1980. Precocene II metabolism: comparative in vivo studies among several species of insects and structure elucidation of 2 major metabolites. Pestic. Biochem, Physiol., 13: 95104.

6. Bowers, W.S. 1982. Toxicology of the precocenes. In Insecticide Mode of Action (Coats, J. R., ed.), pp. 403-427. Academic Press, New York.

7. Bowers, W.S. 1985. Comprehensive Insect Physiology Biochemistry and Pharmacology, G.A. Kerkut and L.I. Gilbert., Vol. 8, Pergamon Press, 551-564.

8. Bowers, W.S.; T. Ohta; J.S. Cleere and P.A. Marsella 1976. Discovery of insect anti-juvenile hormones in plants. Sci. 193: 542-547.

9. Brown, E.S. and C.F. Dewhurst 1975. The genus Spodoptera (Lepidoptera: Noctuidae) in Africa and the Near East. Bull. Entomol. Res., 65: 221-261.

10. Crompton, M. and Birt. 1967. Change in the amount of carbohydrates, phosphagen, and related compounds during the metamorphosis of the blowfly Luciliacuprina. J. Insec. Physiol., 13: 1575-1595.

11. Dhadialla, T.S.; G.R. Carlson; D.P. Le. 1998. New insecticides with ecdysteroidal and juvenile hormone activity.Ann. Rev. Entomol., 43: 545-569. 
12. El-Defrawi, M.E.; A. Toppozada; N. Mansour and M. Zeid 1964.Toxicological studies on the Egyptian cotton leafworm, Prodenialitura (F.) I. Susceptibility of different larval instars of prodenia to insecticides. J. Econ. Entomol., 57: 591-593.

13. Dubios, M.; K.A. Gilles; P.A. Rebersand F. Smith. 1956. Colorimetric method for determination of sugars and related substance. J. Analy. Chem., 28:350-356.

14. Flatt, T.; A. Heyland; F. Rus; E. Porpiglia; C. Sherlock; R. Yamamoto; A. Garbuzov; S.R. Palli; M. Tatar and N. Silverman. 2008. Hormonal regulation of the humoral innate immune response in Drosophila melanogaster., J. Exp. Biol., 211: $2712-2724$.

15. Ishaaya, I. and J.E. Casida. 1974. Dietary TH-6040 alters composition and enzyme activity of housefly larval cuticle. Pestic. Biochem. Physiol., 4: 484-490.

16. Nijhout, H.F. 1994. Insect hormones. Princeton: Princeton Univ. Press, NewJersey, pp. 280.

17. Ohta, T.; R. J. Kuhr and W. S. Bowers. 1977. Radiosynthesis and metabolism of the anti-juvenile hormone, Precocene II. J. Agric. Food. Chem., 25, 478-481.

18. Pratt, G. E. 1983. The mode of action of pro-allactocidins. In Natural Products for Innovative Pest Management (Whitehead, D. L. and Bowers, W. S., eds), pp. 323-355. Pergamon Press, Oxford.

19. Proksch, P. and E. Rodriguez. 1983. Chromenes and benzofurans from the Asteraceae, their chemistry and biological significance. Phytochemistry, 22: 2335-2348.

20. Randriaminahy, M. 1992. Detoxification of naturally occurring chromenes in larvae of the generalist herbivore Spodoptera littoralis (Noctuidae), Biochem. Syst. and Ecol., 8: 711-722.

21. Smagghe, G. and D. Degheele (1994). Action of a novel nonsteroidal ecdysteroid mimics, tebufenozide (RH-5992) on insects of different orders. Pest. Sci., 42: 8592.

22. Soderlund, D.M.; A. Messeguerandand W.S. Bowers. 1980. Precocene II metabolism in insects: Synthesis of potential metabolites and identification of initial in vitro biotransformation products. J. Agric. Food. Chem., 28: 724-731.

23. Srivastava, R. E and P. Proksch. 1991. Contact toxicity and feeding inhibitory activity of chromenes from Asteraceae against Spodoptera littoralis (Lepidoptera: Noctuidae). Entomol. Gen.,15: 265-274.

24. Staal, G.B. 1986. Anti-juvenile hormone agents. Annu. Rev. Entomol., 31: 391429.

25. Tachell, R.J.; S.F. Arman and F.N. Boctor. 1972. Biochemical and physiological studies of certain Ticks. (Ixodoidea). Z. Parsitenk ,9: 345-350.

26. Truman, J.W. and L.M. Riddiford. 2007. The morphostatic actions of juvenile hormone. Insect Biochem. Mol. Biol., 37: 761-770. 


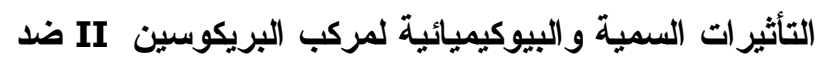

Spodoptera littoralis (Boisd.,) دودة ورق القطن

عبد الجواد علي فهمي ، ممدوح ابراهيم نصار ، عريان شحاته منصور ، أنوار محمد أباظة ، رانيا أمين سلامه

$$
\begin{aligned}
& \text { 1-قسم الكيمياء- كلية العلوم - جامعة القاهرة } \\
& \text { 2-قسم الحشرات - كلية العلوم - جامعة القاهرة } \\
& \text { 3-معرد بحوث وقاية النباتات- مركز البحوث الزراعية - الدقى - مصر }
\end{aligned}
$$

تعتبر دودة ورق القطن من أهم و أخطر الافات التى تصيب معظم المحاصيل الاقتصادية.

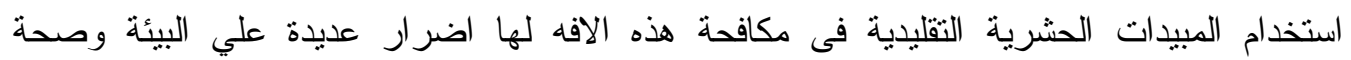

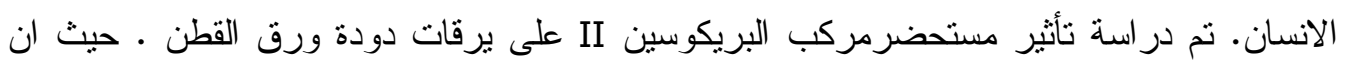
مركب البريكوسين II هو المركب الرئيسى الذى تم فصله من نبات الاجرتيم. أظهرت نتائج السمية

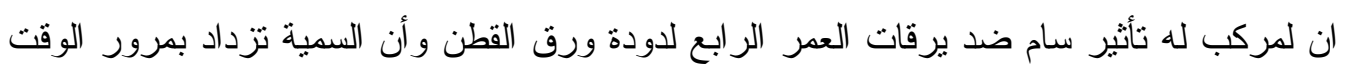

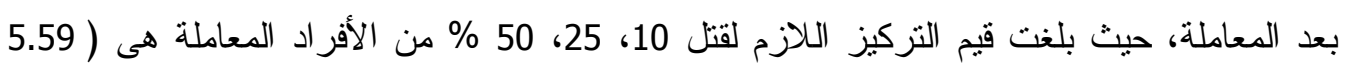

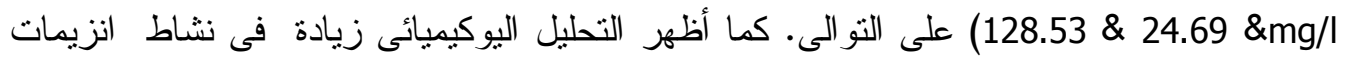
الكيتينيز و البروتييز و الكربو هيدرات بنسبة ( 17.32\& 50.17\& 36.85 على التوالى مقارنة باليرقات 